\title{
Anaphora Resolution in Stream-of-Consciousness Discourse: A Metonymic Account
}

\author{
Wei Zhao ${ }^{1}$ \\ ${ }^{1}$ School of Foreign Languages \& Literature, Shandong Normal University, Jinan, China \\ Correspondence: Wei Zhao, School of Foreign Languages \& Literature, Shandong Normal University, No. 88, \\ East Wenhua Road, Jinan, Shandong 250014, China. Tel: 86-0531-889-2306. E-mail: zhaoweidavid@sina.cn
}

Received: February 26, 2014 Accepted: March 24, 2014 Online Published: May 27, 2014

doi:10.5539/ijel.v4n3p34 URL: http://dx.doi.org/10.5539/ijel.v4n3p34

\begin{abstract}
The present study is devoted to elaborating a metonymic model and principles of anaphora resolution in stream-of-consciousness (SOC) discourse based on metonymic inferential processing to anaphora resolution constrained by the principle of optimal relevance, and then the explanatory power of the model and principles is testified by anaphora occurring in stream-of-consciousness discourse. The research reveals that (1) Idealized Cognitive Model (ICM) functions as the cognitive basis of anaphora resolution; (2) cognitive and pragmatic constraints on anaphora resolution interact, and the division of labor between them can be measured against both conceptual distance between antecedent and anaphor and degrees of optimal relevance; (3) the derived framework may be applicable to other discourse types. In short, anaphora resolution in stream-of-consciousness discourse is actually a cognio-pragmatic inferencing process, in which the hearer/reader achieves optimal relevance based on the conceptual distance between antecedent and anaphor in idealized cognitive models.
\end{abstract}

Keywords: stream-of-consciousness discourse, anaphora, optimal relevance, metonymy

\section{Introduction}

Every single natural language has a rich variety of linguistic means, which can help speakers to refer to entities in the world. The multi-dimension and complexity of anaphora can provide us a window through which the nature of working machinery of human mind and language can be discerned. The research on discourse anaphora resolution has for long been a thorny topic in many fields such as discourse analysis, cognitive linguistics, psycho-linguistics and natural language processing, etc. Over the past twenty or thirty years, many scholars have been devoted to the exploration of motivations and distributional patterns of different types of anaphora in varieties of discourses from different theoretical perspectives. A number of influential anaphoric theories and models abound such as Binding Theory (e.g., Chomsky, 1982), the topic continuity model (e.g., Givón, 1983, 1990), the functional model (e.g., Halliday, 1981, 1985, 1999), the hierarchy model (e.g., Fox, 1987), the revised neo-Gricean pragmatic theory (e.g., Huang, 1991, 1994, 2000), the accessibility model (e.g., Ariel, 1990, 1994), the cognitive reference point model (e.g., van Hoek, 1992, 1995) and centering anaphoric model (e.g., Grosz, Joshi, \& Weinstein, 1986, 1995; Miltsakaki, 1999, 2002, 2007). The above research may point to the future directions of anaphora resolution. Firstly, anaphora research witnesses three turns in its development: (1) the extension of the horizon of anaphora research from intra-sentential to inter-sentential anaphoric research; (2) the multi-functionality trend of anaphora from substitutive substance to cohesive devices to psychological mentality; (3) the perspective shift of anaphoric model construction from static semantic view to dynamic semantic view. The three turns are indicative of the trend of anaphoric research. Secondly, anaphoric distribution in discourse is a very complex phenomenon, involving, among other things, structural, cognitive and pragmatic factors that interact with each other. Huang (2000) points out that of the three interacting factors that are at work in predicting anaphoric distribution in discourse, the structural constraint (both linear and hierarchical) seems largely to be a secondary correlate of the more fundamental cognitive and/or pragmatic constraints (pp. 173-174). However, the interaction and division of labor between cognitive and pragmatic constraints are not well understood and need to be further delved into. Thirdly, different corpora are selected in light of different research purposes, which may contribute to developing a variety of models of anaphora resolution. The selected corpora are mainly oriented towards naturally occurring discourse such as ordinary narrative and conversational discourse. Nevertheless, anaphoric research based on SOC discourse has so far rarely been conducted. 
The extant abundant research on anaphora resolution has laid a very solid foundation for further study. However, the current anaphora research (1) is mainly oriented towards naturally occurring discourse, with scant research devoted to SOC discourse characterized by associative leaps in syntax and narrative non-linearization; (2) the interaction and division of labor between cognitive and pragmatic constraints in predicting anaphoric distribution in discourse is not well understood and need to be further explored. Based on previous research, the present study aims to investigate the cognitive and pragmatic constraints on anaphora resolution, i.e., the interaction and division of labor between them in SOC discourse. The metonymic anaphoric model and principles are then proposed. The segments excerpted from Wang Meng's and James Joyce's SOC novels are employed to corroborate the predictive and explanatory power of this anaphoric model and principles. Therefore, this anaphoric research is endowed with a new perspective.

\section{A metonymic Account of Anaphora in Stream-of-Consciousness Discourse}

This section is dedicated to elaborating a metonymic model and principles of anaphoric distribution in SOC discourse. In what follows the rationales of the proposed theoretical framework will be discussed. Panther and Thornburg (2003) have convincingly demonstrated that purely pragmatic accounts are incapable of drawing detailed enough metonymic inferences, and that the conceptual approach to metonymy advocated in cognitive linguistics is also insufficient for explaining realistic metonymic readings. Quite in line with this view, Gibbs (2007) suggests that the interpretation of referential metonymies relies on our ability to quickly access both specific pragmatic knowledge and a conceptual metonymy, and integrate these two kinds of information to construct an appropriate reading. Put differently, understanding metonymy requires important mutual adjustment processes accessing both conceptual and pragmatic inferencing during online meaning construction. Based on this insight, a metonymic account of anaphora resolution in SOC discourse is proposed below, in which conceptual metonymy and pragmatic inferencing to achieve optimal relevance are integrated to provide a plausible account for SOC discourse anaphora resolution.

\subsection{Dynamic Context under Relevance Theory}

Context plays a central role in humans' communication. Context under Relevance Theory (Sperber \& Wilson, 1986), refers to the set of mentally represented assumptions invoked in interpreting an utterance, in which process the encyclopedic knowledge, logical knowledge and lexical knowledge are evoked. In contrast to the latter, context is a comprehensive and dynamic concept, during which mutual knowledge of communicators develops dynamically as the communication progresses, continuously incorporating incoming new information into the dynamic context.

Relevance Theory assumes, although there are various assumptions available in a potential context at a given point, not every assumption available is equally accessible. Different degrees of accessibility of contextual assumptions make themselves felt by the amount of efforts required in a particular act of communication. This sensitivity to processing efforts is crucial for the success of inferential communication, and anaphora resolution in particular.

\subsection{Maximal Relevance vs. Optimal Relevance}

According to Sperber and Wilson (1986), two principles of relevance are proposed, with one governing cognition and the other communication: (1) Maximal Relevance, which pursues more "gain", but tries to lose less "cost"; (2) Optimal Relevance, which pursues a balance between "gain" and "cost". Relevance Theory suggests that human communication crucially achieves optimal relevance, rather than maximal relevance, i.e., optimal relevance is not "the most relevant", but the adequate relevance. Optimal relevance is defined as an utterance, on a given interpretation, is optimally relevant iff:

(a) it is relevant enough to be worth the hearer's attention;

(b) it is most relevant one the speaker is able and willing to produce.

From the definition, it can be seen that two conditions are supposed to be satisfied to gain optimal relevance:

(a) The contextual effects of an utterance are strong enough to hold the hearer's/reader's attention;

(b) The most relevant utterance type produced by the speaker depending on his/her abilities and preferences on the one hand; and inferential efforts the hearer makes for gaining enough contextual effects on the other hand.

The writers of SOC novels are able and prefer to use non-stereotypical anaphoric expressions to express intricate thoughts and emotions. Hence, the selection of anaphoric expressions, which are strong enough to attract the hearer's/reader's attention, is quite against the normal patterns in ordinary narrative and conversation. Additionally, the hearer/reader will make some inferential efforts to gain enough contextual effects. There must 
be a balance between the gain of contextual effects and the expense of inferential efforts. Simply put, the greater inferential efforts expended in anaphora resolution, the greater the contextual effects; the less inferential efforts in anaphora resolution, the less the contextual effects.

\subsection{Metonymy in Meaning Construction}

Metonymy is traditionally defined as a process of substituting one word for another with which it is associated. Barcelona (2002, p. 246) defines metonymy as "a mapping of a cognitive domain, the source, onto another domain, the target. Source and target are in the same functional domain and are linked by a pragmatic function, so that the target is mentally activated." By "functional domain", Barcelona means an "Idealized Cognitive Model" in Lakoff's (1987) terms. Al-Sharafi (2004) argues from a semiotic perspective metonymy is a process of REPRESENTATION in which one word or concept or object stands for another by contiguity or causality. Metonymy as representation cuts across the ontological, epistemological and linguistic dimension.

Conceptual metonymy plays a central role in ordinary meaning construction (Panther \& Thornburg, 2003). A significant part of Panther and Thornburg's claim is that metonymy provides what they refer to as "natural inference schemas", because these schemas reflect recurrent, entrenched conceptual mappings. Conceptual metonymies reflect an intermediate level of inferential reasoning, precisely because they are sufficiently abstract to serve a wide variety of inferential situations, and yet are specific enough to provide detailed accounts of meaning construction in specific contexts of language use.

Metonymy shapes language, thought, and more specifically, pragmatic inferencing (Panther \& Radden, 1999; Panther \& Thornburg, 2003). It provides an important constraint on pragmatic inferential processes, and that conceptual factors are clearly integrated with pragmatic ones in utterance interpretation. In other words, pragmatics alone is insufficient to account for immediate meaning construction and needs to be reinforced by available, and often quite accessible, metonymic mappings, such as those potentially represented by conceptual metonymies.

Thus, we suggest that conceptual metonymies interact with pragmatic inferencing to create specific, contextually-appropriate inferences based on writers' utterances to approach SOC discourse anaphora resolution.

\subsection{Rationales of the Proposed Theoretical Framework}

\subsubsection{Stream-of-Consciousness Discourse}

The distributional pattern of anaphora in SOC discourse differs from ordinary narrative and conversational discourse because a discourse of this type unfolds in a bouncing manner and covering a great span of time via shuttling from the past to the present and even to the future.

Although SOC discourse is created as chaotic as possible, there are still some important clues left by writers for readers to trace and decode the underlying meaning behind the superficial chaos. One thing needs to be noted is that chaos in SOC discourse are elaborately devised. Although consciousness streams like water and sometimes may have twists and turns, the focus at a particular moment is supposed to be on a single matter, some relations may be drawn between two contiguous, irrelevant ideas. As a result, anaphoric distribution as an important clue to the interpretation of SOC discourse may have its own distinctive features.

\subsubsection{Optimal Relevance Principle}

Discourses are ostensive stimuli whose purposes are arguably communicative, and SOC discourse is no exception. The first task of the reader is to arrive at the intended interpretation of the text, i.e., to derive an adequate subset of assumptions made manifest by the writer. According to optimal relevance principle, the cognitive efforts the hearer/reader makes are in positive correlation with the contextual effects $\mathrm{s} /$ he gets. In SOC discourse, a writer who intends to communicate intricate thoughts or emotions to readers, involving emotional or non-propositional content such as impressions, may choose relatively incomprehensible, indirect, and suggestive utterances. Metonymic uses fall clearly into this case. The greater efforts the interpretation of utterances of this sort requires are offset by the extra effects gained. As the principle of relevance states, every act of ostensive communication carries a guarantee of its own optimal relevance. The metonymic utterance, like all utterances, relies on the ability of the hearer/reader to arrive at an interpretation consistent with this principle. Relevance constraints predict that a writer will use a metonymy only when s/he believes that implicating one thing by referring to another will allow the reader to arrive at the intended reference without any unrewarding processing effort. If some extra efforts are involved, it will allow the reader to derive a wide range of contextual effects than referring directly to the object would have done. Specifically speaking, the use and interpretation of metonymy depends on inference, constrained by the guarantee of optimal relevance that accompanies all ostensive stimuli. 


\subsubsection{The Tripartite Division of Metonymy}

Metonymic signification cuts across domains (Radden \& Kovecses, 1999, p. 21), namely, the domain of words, the domain of concepts and the domain of objects. This triadic semiotic interaction between these three worlds makes the role of metonymy in binding text very critical in accounting for the interactive nature of textual communication between these worlds. The major types of metonymy are shown as follows:

The metonymy of one concept as the substitution of another due to the interaction between concepts in a domain:

A: Concept (A) for Concept (B)

The metonymy operation cuts across two different domains based on the interaction between form and concept:

B: Form (A) for Concept (A)

The metonymy based on the interaction between concept and thing domains:

C: Concept (A) for Thing (A)

The metonymy based on the interaction between two forms and one concept, usually in the forms of acronyms and abbreviations:

E: Form (A)-Concept (A) for Form (B)-Concept (A)

Moreover, the textual metonymy model by Al-Sharafi (2004) argues that textual metonymy is composed of two levels, i.e., the level of formal signification (also the level of cohesion) which involves five metonymic relations: (a) CONCEPT FOR FORM; (b) FORM FOR FORM; (c) FORM FOR CONCEPT; (d) FORM FOR THING; (e) THING FOR FORM. The second level of cognition (also the level of coherence) combines the realm of concepts as well as the realm of objects. The relations at this level are represented as: (f) CONCEPT FOR CONCEPT; (g) CONCEPT FOR THING; (h) THING FOR THING; (i) THING FOR CONCEPT. Broadly speaking, the substitution between form, concept and thing can be regarded as metonymic relations, i.e., all references are metonymic.

\subsubsection{The Conceptual Distance between Antecedent (Metonymic Trigger) and Anaphor (Metonymic Target)}

The link between a metonymic source and its target may vary in strength (Panther \& Thornburg, 2003, p. 6). The strength of a metonymic link depends on how conceptually close source and target are to each other. It has a scale of conventionality like metaphor. Some have been conventionalized, whereas some are nonce-words produced in dynamic context, and cannot be conventionalized. Associations that support metonymy fall roughly into "intrinsic associations," which are either inherent, or at least relatively permanent, and "extrinsic associations," where A and B are associated contingently and non-inherently (Croft \& Cruse, 2004, p. 217). In other words, metonymy based on intrinsic associations is characteristic of conventionality, whereas metonymy based on extrinsic associations is not.

Therefore, the strength of a metonymic link is determined by contiguity between antecedent and anaphor. The conceptual distance between them can be measured against the strength of a metonymic link, specifically, strong conventionalized metonymy and nonce metonymy.

\subsection{A Metonymic Model of Anaphora Resolution in Stream-of-Consciousness Discourse}

Based on the rationales formulated above, a metonymic model of anaphora resolution is elaborated as below. 


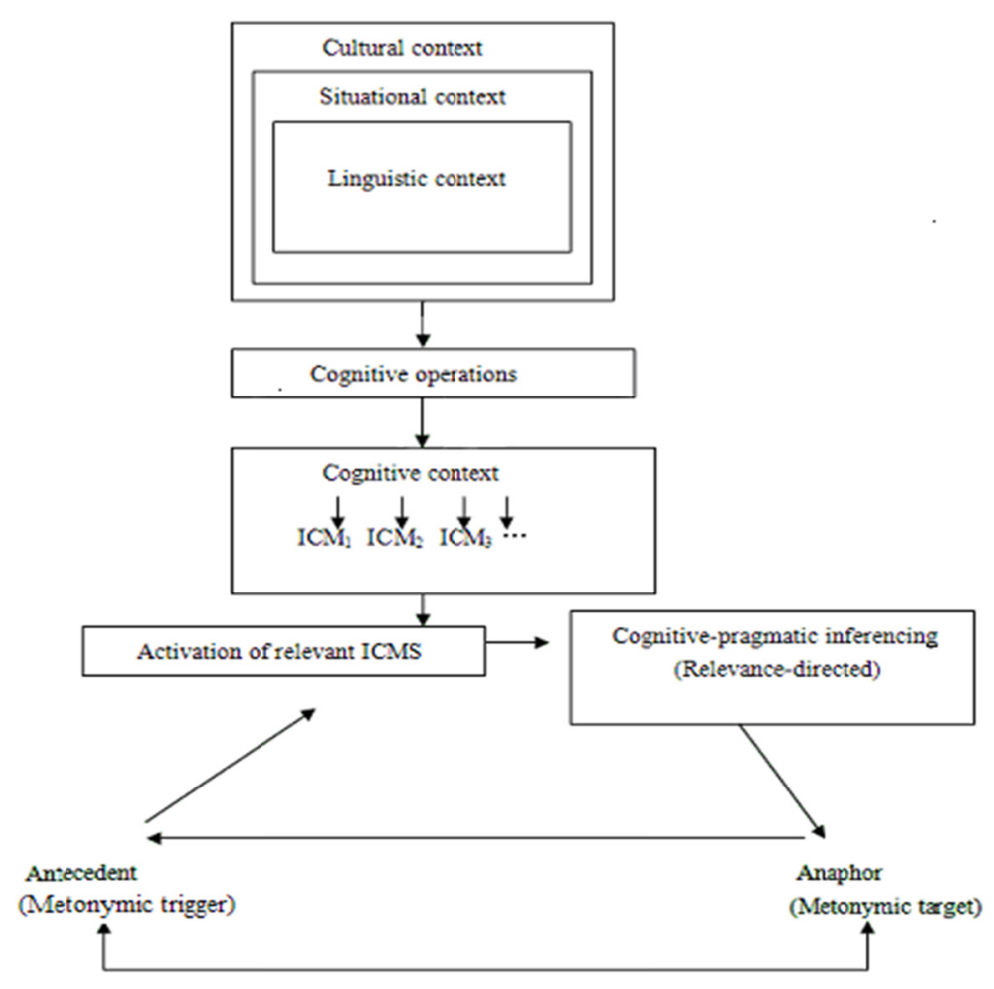

Figure 1. A metonymic model of anaphora resolution

In the figure above, anaphora is viewed as cutting across three worlds, i.e., the world of forms, the world of concepts and the world of things. The relation between antecedent and anaphor can be explained via metonymic relations, namely, CONCEPT FOR FORM, FORM FOR FORM, FORM FOR CONCEPT, FORM FOR THING, THING FOR FORM, which are subsumed into the first level of formal signification in text. The second level of cognition is represented by such four relations as CONCEPT FOR CONCEPT, CONCEPT FOR THING, THING FOR THING, and THING FOR CONCEPT. Linguistic context, situational context and cultural context will undergo a series of cognitive operations to evolve into cognitive context composed of numerous concrete ICMs. In the anaphoric resolution process, firstly, an antecedent (metonymic trigger) activates relevant ICMs in the hearer's/reader's mind based on the conceptual distance between antecedent and anaphor. Then, optimal relevance may be sought between them. Therefore, we can hypothesize that anaphora resolution is first preconditioned on the conceptual distance between antecedent and anaphor, which can be measured against different metonymic relations, i.e., strong conventionalized metonymy and nonce metonymy. That is, strong conventionalized metonymy $=1$; nonce metonymy $=2 \ldots$ Second, optimal relevance between antecedent and anaphor may be scaled against the positive correlation between cognitive efforts and contextual effects, i.e., the steps cognio-pragmatic inferencing takes (e.g., 1 inferencing step $=1 ; 2$ inferencing steps $=2 \ldots$ ). Hence, the relation between antecedent and anaphor can be defined by the sum total of the two values. And the higher the total is, the less mentally accessible the encoding of antecedent is, and vice versa.

\subsection{The Metonymic Principles of Anaphora Resolution}

Based on the proposed model above, in what follows, we can derive some metonymic principles of anaphora resolution.

a. The closer the conceptual distance between antecedent and anaphor is, the smaller cognitive efforts a hearer/reader takes.

b. The farther the conceptual distance between antecedent and anaphor is, the greater cognitive efforts a hearer/ reader takes.

c. The smaller cognitive efforts a hearer/reader takes, the weaker the contextual effects.

d. The greater cognitive efforts a hearer/reader takes, the stronger the contextual effects. 
e. The weaker the contextual effects, the less mentally accessible the encoding of anaphor.

f. The stronger the contextual effects, the more mentally accessible the encoding of anaphor.

\section{The Application of Metonymic Principles of Anaphora Resolution to SOC Discourse}

\subsection{Identical Expressions for Metonymic Relations of "Thing for Concept"}

3.1.1 Identical Expressions for Metonymic Relations of Explicit "Thing for Concept"

(1) 穿着红色旗袍的司马莉;

Si Mali in red cheongsam;

穿着紫色过腰短衫与白色过膝短裙的司马莉;

Si Mali in purple blouse and white knee-length skirts;

穿着三点游泳衣的司马莉;

Si Mali in bathing suit;

穿着运动衫的司马莉;

Si Mali in sports shirt;

穿着晚礼服的司马莉;

Si Mali in evening gown;

穿着灰色短褛与灰色百褶裙的司马莉;

Si Mali in grey jacket and grey skirt with accordion pleats

穿着古装的司马莉;

Si Mali in ancient costume;

以及不穿衣服的司马莉; …...

and Si Mali with nothing on;...

几十个司马莉; 穿着十几种不同的服装, 犹如走马灯上的纸人, 转过去, 转过来, 出现在我的脑 海中, 永无停止。

Dozens of Si Mali in a dozen of different clothes turn from side to side like the paper mannikin in the revolving scenic lamp, emerging in my mind endlessly. (Liu Yichang, The Drunkard)

In example (1), paper mannikin as a bridge connecting between segments, plays a decisive role in discourse coherence. The metonymic relation between "Si Mali" and paper mannikin is THING FOR CONCEPT. "Si Mali" in different clothes (THING) is used for a multi-facial "Si Mali" (CONCEPT), "Si Mali" (THING) for a multicharacter "Si Mali" (CONCEPT). The frequent transformation from "Si Mali" to paper manikin, and then from paper mannikin to "Si Mali", and finally from "Si Mali" to diverse impressions on "Si Mali" involves complex cognio-pragmatic inferencing. Therefore, nominal phrases other than attenuated pronouns or zero pronouns are employed in anaphora assignment. Readers can discern that multi-facial "Si Mali" and multi-dimensional "Si Mali" in the eyes of different people are compared to paper mannikin, capricious and incomprehensible. Every aspect of her character is indispensable to an all-round "Si Mali". Thus, the anaphoric chain of "Si Mali" seems redundant, but in effect essential. The "Si Mali" chain can be diagrammed as below:

Cognio-pragmatic inferencing in the "PAPER MANNIKIN" ICM is involved in achieving optimal relevance between antecedent and anaphor:

(1) activation of the "PAPER MANNIKIN" ICM;

(2) different qualities of "Si Mali" compared to different dimensions of paper mannikin.

Thus, nonce metonymy $=2$, inferencing step $=1$, the sum total $=3$. The encoding of anaphora tends to be mentally inaccessible.

3.1.2 Identical Expressions for Metonymic Relations of Implicit "Thing for Concept"

(2) 在张丽丽面前, 我永远是一个失败者。

Before Zhang Lili, I am always a loser.

在张丽丽面前, 我的感情被肢解了。

Before Zhang Lili, my feeling is dismembered 
在张丽丽面前, 我必须隐藏自己的狼狈。

Before Zhang Lili, I must hide my embarrassment.

在张丽丽面前, 我像小学生见到暴躁的教师。

Before Zhang Lili, I seem to see my irascible teacher like a pupil.

在张丽丽面前, 我擎起白旗。

Before Zhang Lili, I hoist the white flag. (Liu Yichang, The Drunkard)

This segment is a vivid delineation of the protagonist reduced to a slave to love. Through colored lenses of the protagonist the image of "Zhang Lili" (THING) is magnified, hence quite salient and powerful in the "LOVE" ICM. Compared with over-exaggerated Goddess Zhang (CONCEPT), I am under-sized in the fictional world of love, always secondary to her glamour. The imbalance between the lover and the loved foregrounds the two parties involved, i.e., the symbol of the Goddess and the coward based on the metonymic relation of "THING FOR CONCEPT". Thus, a chain of unattenuated proper names "Zhang Lili" is employed.

In the "LOVE" ICM, cognio-pragmatic inferencing is involved in achieving optimal relevance between antecedent and anaphor:

(1) activation of the "LOVE" ICM;

(2) colored lenses of the protagonist;

(3) over-exaggerated "Miss Zhang".

Thus, the metonymic relation of implicit "Thing for Concept" between real "Zhang Lili" and illusory "Zhang Lili" is established. The resolution of the anaphoric chain can be fulfilled via two steps (1) conventionalized metonymy $=1 ;(2)$ inferential step $=2$. The sum total $=3$. The encoding of anaphora tends to be mentally inaccessible.

\subsection{Metonymic Relations of "Thing for Thing"}

3.2.1 Identical Expressions for Metonymic Relation of "Thing for Thing"

(3) 我走进一面偌大的镜子

I enter into a big mirror

在镜子里找到另外一个世界

I find another world there

这个世界和我们现在所处的世界极其相似然而不是我们现在所处的世

The world is quite similar to our world, but not the world we are in

这个世界里有我

There am I in the world

然而不是莪

But not I

这个世界里有份

There are you in the world

然而不是份

But not you

这个世界里有他

There is he in the world

然而不是他

But not he

这是一个奇异的世界犹如八卦阵一般教每一个人走到里边去寻找自己

This is fantastic world like Eight-Diagram tactics, which teaches everyone to go inside to find himself 在这个世界里恋爱不是双方面的事每一个人都爱自己

In this world love involves not only both sides, everyone loves himself 


\section{在这个世界里人们可以从自己的额角上看到时间的脚印}

In this world people can discern the footprint of time on the forehead

在这个世界里皇发与急纹是两样最可憎的东西

In this world grey hair and wrinkles are most obnoxious

在这个世界里只有眼睛最真实除此之外都是影子

In this world every thing is a shadow except that the eyes can be trusted. (Liu Yichang, The Drunkard)

In example (3), the author's portrayal of the mirror world activates a fictional "MIRROR WORLD" ICM in readers' mind. In the "MIRROR WORLD" ICM, cognio-pragmatic inferencing is expected to be made to achieve optimal relevance between antecedent and anaphor:

(1) activation of a fictional mirror world;

(2) absurdity and unconventionality of the mirror world;

(3) dislocation and abnormality of the people in the mirror world;

(4) saliency and enlargement of figures.

Firstly, in the "world" anaphoric chain, The conceptual distance between the real world and the fictional world can be measured by the sum total "3", i.e., (1) nonce metonymy $=2$; (2) inferencing step $=1$;. Thus, full noun phrase "the world" echoes throughout the whole segment. Secondly, the first person plural "we" comprised of "I", "you", and "he". The "we" image in real world does not accord with that in the fictional world. Therefore, no zero pronouns are used in the anaphoric chain. The relations between "forehead", "grey hair", "wrinkles", "eyes", "shadow" and "people" are part-for-whole metonymy. The resolution of this anaphoric chain can be fulfilled via two steps: (1) strong conventionalized metonymy $=1 ;(2)$ inferencing step $=3$. The sum total $=4$. The encoding of anaphora tends to be mentally inaccessible.

\subsubsection{Partially Identical Expressions for Metonymic Relation of "Thing for Thing"}

(4) 那个坐着吉姆牌轿车, 穿过街灯明亮、两旁都是高楼大厦的市中心的大街的张思远副部长和 那个背着一篓子羊粪, 屈背弓腰, 咬着牙行走在山间的崎岖小路上的“老张头”, 是一个人吗? 他 是“老张头”, 却突然变成了张副部长吗？他是张副部长, 却突然变成了“老张头”吗？这真是一个 有趣的问题。抑或他既不是张副部长也不是老张头, 而是他张思远自己？（王蒙《蝴蝶》）

Is vice deputy director Zhang Siyuan who is seated in a Jim, crossing the downtown area with bright street lamps and highrises, the same person with "Lao Zhang" who carries a basket of goat shit walking on the unpaved track, with hunch backed, and teeth set? Is "Lao Zhang" suddenly changed into vice deputy director Zhang? Is vice deputy director Zhang suddenly changed into "Lao Zhang"? This is a quite interesting problem. Maybe he is neither vice deputy director Zhang nor Lao Zhang, but only himself. (Wang Meng, The Butterfly)

In this segment, the hero of the novelette, Zhang Siyuan ponders upon the transformation of his identities in two different socio-political contexts, trying to figure out what lies behind different appellation of the same person "Zhang Siyuan". The present deputy director Zhang and Lao Zhang in the period of Cultural Revolution belong to two discrete points in the temporal scale of Zhuang Siyuan's lifetime. Readers can be aware that they are interconnected and bridged by Zhuang Siyuan per se via the activation of "LIFETIME" ICM. The following cognio-pragmatic inferencing in this ICM is undergone to achieve optimal relevance between antecedent and anaphor:

(1) activation of "LIFETIME" ICM;

(2) present deputy director Zhang;

(3) Lao Zhang in the period of Cultural Revolution;

(4) Zhuang Siyuan per se.

A metonymic relation of "thing for thing" is established. Thus, the resolution of this anaphoric chain can be fulfilled via two steps (1) strong conventionalized metonymy $=1 ;(2)$ inferencing step $=3$. The sum total $=4$. The encoding of anaphora tends to be mentally inaccessible.

\subsubsection{Associative Anaphora for Metonymic Relation of "Thing for Thing"}

(5) He bent down to regard a lean file of spearmint growing by the wall. Make a summerhouse shere. $^{-}$ $\underline{\text { Scarlet runners }}$. Virginia creepers . Want to manure the whole place over, scabby soil. A coat of liver of 
sulphur. All soil like that without dung. Household slops. Loam, what is this that is? The hens in the next garden: their droppings are very good top dressing. Best of all though are the cattle, especially when they are fed on those oilcakes. Mulch of dung. Best thing to clean ladies' kid gloves. Dirty cleans. Ashes too. Reclaim the whole place. Grow peas in that corner there. Lettuce. Always have fresh greens then. Still gardens have their drawbacks. That bee or bluebottle here Whitmonday. (Joyce, Ulysses)

In this segment, the three anaphoric chains are diagrammed as follows:

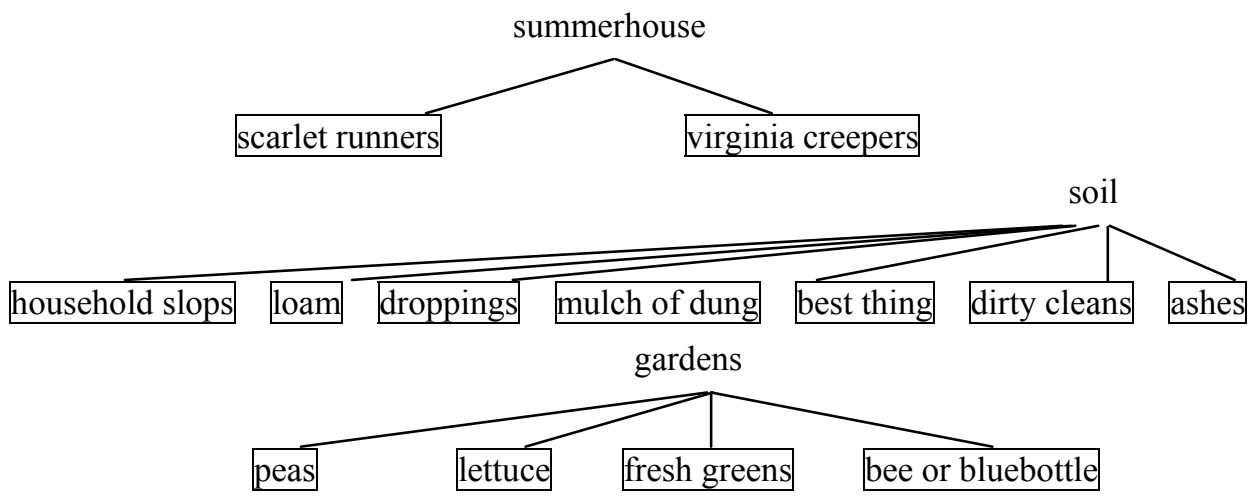

To achieve referential success, three ICMs such as "SUMMERHOUSE", "SOIL" and "GARDEN" are supposed to be activated in readers' mind to gain optimal relevance between antecedent and anaphor, in which cognitive efforts are expended against the contextual effects to be obtained. Hence, first, in the "SUMMERHOUSE" ICM, nonce metonymy $=2$, inferencing step $=1$, the sum total $=3$; second, in the "SOIL" ICM, nonce metonymy $=2$, inferencing step $=1$, the sum total $=3$; third, in the "GARDEN" ICM, nonce metonymy $=2$, inferencing step $=1$, the sum total $=3$, the encoding of anaphora tends to be mentally inaccessible.

\subsubsection{Associative Anaphora for Metonymic Relations of "Thing for Thing" and One-Trait "Thing for Concept"}

（6）你不是也爱这个售货员吗? 她用奥斯曼草把眉毛染成了墨绿色，用凤仙花把指甲和手心染成 了橙红，她说话的时候细声细气，她的耳朵上有戴红宝石做的耳环，她习惯地吸吮一下娇小的鼻 子，露出了鼻尖上的细小的、可笑的皱纹。当她把两个圆锥形的纸包递给你，又从你的手里接过 去两张一元钱的纸币的时候，她向你笑了一下。如果不是在这个边远的少数民族地区，你能够看 得到这样纯净的笑容么？1944 年, 他 13 岁的时候, 突然被音乐征服了。......那天晚上, 他失眠 了，他醉迷了，他发狂了。他从来没有听到过，没有想到过，在人们的沉重的灰色的生活里， 还能出现一个如此不同的, 光明而又奇妙的世界。他从来不知道人们会想象出、创造出、奏出和 发出这样优美、这样动人、这样绝顶清新而又结构井然的作品。他一晚上不睡, 看着月亮, 试着 用自己的喉咙, 用自己的发声器官来模拟这些音乐和歌曲, 这些音乐和歌曲他只听了一遍, 便已 经滞留在他的心灵里了…… (王蒙《杂色》)

Don't you like the salesgirl? She dyed her eyebrows jasper with woad, and her fingernails and palm

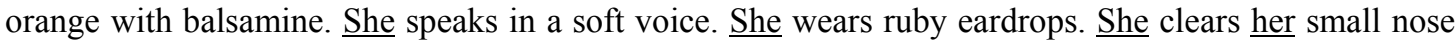
by habit, with tiny and funny wrinkles on the tip of her nose. When she passed two cone-shaped packs to you, and received two one-yuan bills from you. She smiled at you. If it doesn't happen in the remote ethnic minority regions, you can not see such pure smile? In 1944, at the age of 13, he was conquered by music. ... That evening,hewas sleepless; he was intoxicated; he was crazy. He had never heard or thought that there emerges such different, bright and marvelous world in the heavy and grey life of humans. It never occurred to him that humans could imagine, create, play and sing such ultimately fresh and well-structured piece of music. He could not sleep all night, looking up at the moon, attempting to imitate these music and songs with his throat and his speech organs. He listened to these music and songs only once, but they had already lingered in his mind... (Wang Meng, Motley)

In this segment, three temporal segments of the past, the present and the future are essential to the "HUMAN" ICM, which are adjacent in terms of time. "You"- the present "Cao Qianli" (THING) and "he"- the 1944 "Cao Qianli" (THING) can be viewed as an episode of his life. A part-for-whole metonymic relation based on "THING FOR THING" is established. Embedded in this ICM are two similar subsegments which delineate a beauty-overwhelmed "Cao Qianli". The anaphoric chain of "she" likened to the symbol of beauty arises on the basis of the metonymic relation "THING FOR CONCEPT". The co-reference between "you" and "he", and between "she" and "music" can be realized via inferencing below:

(1) activation of "Cao Qianli" in two different temporal-spatial settings; 
(2) similarity between two images of "Cao Qianli" to pursue beautiful things;

(3) unity between "you" and "he" and between "she" and "music".

Therefore, nonce metonymy $=2$, inferencing step $=2$, the sum total $=4$. The encoding of anaphora tends to be mentally inaccessible.

3.2.5 Associative Anaphora for Metonymic Relations of Opposite-Trait "Thing for Concept"

(7) 审判

A: 我请求判我的罪。

B: 你是无罪的。

A: 不。那有轨电车的叮当声, 便是海云的青春和生命的挽歌, 从她找到我的办公室的那一天起, 便注定了她的灭亡。

$\mathrm{B}$ : 是她找的你。是她爱的你。你曾经给她带来幸福。

A: 但是你爱她。真的吗? (王蒙《蝴蝶》)

The Trial

A: $\underline{\underline{I}}$ ask to be sentenced for my sins.

B: You are innocent.

A: No. the clink of trams is an elegy to Haiyun's youth and life. From the day she met me in my office, she was destined.

B: It is she that came to meet you. It is she that she fell in love with you. And you had brought her happiness.

A: But do you really love her? (Wang Meng, The Butterfly)

In this segment, a dialogue between "I" and "You", actually, a soul battle between good and evil unfolds before readers. The title "Trial" activates the "TRIAL" ICM, in which the protagonist plays dual roles: the judge (THING) and the accused (THING). One is to unwaveringly administer justice while the other is to pass the buck. The metonymic relation of opposite-trait "Thing for Concept" is deployed to represent the complexity of human nature, a mixture of good (CONCEPT) and evil (CONCEPT). The co-reference of "you" and "I" chains can be realized via inferencing below:

(1) activation of the "TRIAL" ICM;

(2) angle side and devil side of a person;

(3) unity of "you" and "I" in one person.

Therefore, nonce metonymy $=2$, inferencing step $=2$, the sum total $=4$. The encoding of anaphora tends to be mentally inaccessible.

\subsection{Associative Anaphora for Metonymic Relation of "Concept for Thing"}

\subsubsection{Associative Anaphora for Metonymic Relation of "Concept for Thing"}

(8) A kidney oozed bloodgouts on the willowpatterned dish: the last. He stood by the nextdoor girl at the counter. Would she buy it too, $\varnothing$ calling the items from a slip in her hand? Chapped: washing soda. And a pound and a hailf of Denny's sausages.// His eyes rested on her vigorous hips. Woods his name is. Wonder what he does. Ø Wife is oldish. New blood. No Ø followers allowed.// Strong pair of arms. Ø Whacking a carpet on the clothesline. She does whack it, by George. The way hẹr crooked skirt swings at each whack. (James Joyce, Ulysses)

The focus of the excerpt is on the nextdoor girl. The interpretation of this free association segment by "Bloom" is based on the conceptual distance between antecedent and anaphor. It can also be assumed that there exists optimal relevance between them. That is, conventionalized metonymy based on "CONCEPT FOR THING" is employed to foreground "hands", "hip" and "arms", that is, the value (CONCEPT) of the maid, to deepen readers' understanding of her (THING). She has fallen into a slave of "Woods" both in housework and in bed. Her image is vague in readers' mind. However, what is eye-catching are the organs which may represent her value — chapped hands, vigorous hips, and strong arms.

The "HIP" ICM activates a frame that wife is oldish and husband has an affair with the maid. The writer deploys topicalized clause- -Woods his name is" to purposefully put "Woods" and "hip" together, which aims to imply 
the unusual relation between "Woods" and the maid. "Woods" chain: "Woods—his name—he" is direct and clear, whereas "wife-blood-followers" are associative anaphora which may be accounted for via pragmatic inferencing below:

(1) activation of "HIP" ICM;

(2) illegal relation between "Woods" and the girl servant;

(3) oldish wife in contrast with a budding maid with followers disallowed.

Hence, in the "hip" associative anaphoric chain, nonce metonymy $=2$, inferencing step $=2$, the sum total $=4$, the encoding of anaphora tends to be mentally more inaccessible. Associative nouns are preferable. In "Woods - his name- he" chain, conventionalized metonymy $=1$, inferencing step $=1$, the sum total $=2$, the encoding of anaphora tends to be mentally accessible. Pronouns are preferred.

3.3.2 Associative Anaphora for Metonymic Relation of "Concept for Thing"

(9) 金下的想象，雨水再次受到挫折。远方的一株楖不过是一个古怪的联想。凡是年轻人，总爱 追求两个太阳。怀疑如小偷般潜匿在角隅，不敢动弹。大胆的愿望，恰被惊怯的踌躇所阻。我不 像是个有胆量的䙲人, 投小石于心池中, 泛起几圈涟渏, 一若海鸥点水。那午夜的爱情是合法的, 但是好奇的男女皆不注意阳光的角度。想喝一杯酒, 酒瓶已空。失望常是冰凉的, 舞蹈家在梦境 中断了鞋带。她舒口气, 眼睛里仍有振奋的神情。然而这想念并未给我太多的鼓舞。

Imagination under an umbrella, raindrops are set back again. The tree in the distance is nothing but an odd association. Young men aspire to pursue two suns. Suspicion is like a thief hided in the corner, and dare not move. Audacious wish is held back by hesitation out of fear. I am not a man of courage, throwing a stone into the pond of heart with wrinkles of ripples like seagulls skimming the surface of water. Love at midnight is legal. But curious man and women do not notice the angle of sunlight. I want to have a drink, but the bottle is empty. Disappointment is icy cold. The dancer broke a shoe lace in her dream. She heaves a sigh, with an invigorating look in her eyes. However, it doesn't give me too much encouragement. (Liu Yichang, The Drunkard)

In this segment, three associative anaphoric chains listed as follows are established by invoking an ICM about a dare-not-respond love of the protagonist towards "Si Mali".

(1) activation of a "DARE-NOT-TO-RESPOND LOVE" ICM;

(2) symbol (rain) of woman vs. symbol (umbrella, tree) of man;

(3) woman's emotions and qualities (CONCEPT) for woman vs. man's emotions and qualities (CONCEPT) for man.

In this segment, the properties of "She" and "I" chains are first metaphorically realized through cognitive operations by projecting the characteristics of the source domain "rain" to the target domain "she" or "umbrella" to "I"; second they co-refer with each other via metonymic relation of "Concept for Thing", achieving optimal relevance between anchor and anaphor. Nonce metonymy based on extrinsic association "she-raindrops - disappointment-young men — dancer" and "I—umbrella-tree-suspicion—audacious wish" $=2$, inferencing step $=2$, the sum total $=4$, the encoding of anaphora tends to be mentally more inaccessible.

\subsection{Anaphora for Metonymic Relation of "Concept for Concept"}

\subsubsection{Non-Explicit Antecedent Anaphora for Metonymic Relation of "Concept for Concept"}

(10) 二加二等于五。酒瓶在桌面踱步。有脚的思想在空间追逐。四方的太阳。时间患了流行性感 冒。茶与咖啡的混合物。香港到了第十三个月就会落雪的。心灵的交通灯熄灭了。眼前的一切为 什么皆极模糊?（刘以㚛《酒徒》

Two plus two equals five. The winebottle is strolling on the table. Footed thought is chasing something in space. The square sun. Time catches a flu. The mixture of tea and coffee. Hongkong will be snowing in the thirteenth month. The traffic lights of my heart has gone out. Why is everything so vague before me? (Liu Yichang, The Drunkard)

The antecedents of all anaphors in this segment are not explicitly stated. The whole segment seems chaotic and perverse. However, if the "ECSTASY" ICM out of drunkenness is activated, the above abnormality turns out to be quite normal. Thus, metonymic relation of "Concept for Concept" is employed to represent the contradiction between an orderly world (Concept) and abnormal reality (Concept). The inferencing below is supposed to be made for the resolution of these anaphors without explicit antecedents: 
(1) activation of the "ECSTASY" ICM;

(2) insanity and irrationality of the hero at that time.

Therefore, nonce metonymy $=2$, inferencing step $=1$, the sum total $=3$. The encoding of anaphora tends to be mentally inaccessible.

\subsubsection{Explicit Antecedent Anaphora for Metonymic Relation of "Concept for Concept"}

(11) Shouts rang shrill from the boys' playfield and a whirring whistle.

Again: a goal. I am among them, among their battling bodies in a medley, the joust of life. You mean that knockkneed mother's darling who seems to be slightly crawsick? //Jousts. Time shocked rebounds, shock by shock. Jousts, slush and uproar of battles, the frozen deathspew of the slain, a shout of spearspikes baited with men's bloodied guts. (Joyce, Ulysses)

In this segment, the scene of children's playing football on the playfield evokes a "BATTLING" ICM compared to "the joust of life" in Stephen's mind. The "battling" anaphoric chain of "bodies - the joust of life-jousts-jousts, slush and uproar of battles" reflects the metonymic relation of "Concept for Concept", i.e., battling on the playfield is compared to "the joust of life", and then to the battlefield. What these three concepts share is cruelty and fierceness. The resolution of these anaphors with non-explicit antecedents is supposed to follow the inferencing steps below:

(1) activation of a "BATTLING" ICM;

(2) battling on the playfield compared to the joust of life.

Therefore, nonce metonymy $=2$, inferencing step $=1$, the sum total $=3$. The encoding of anaphora tends to be mentally inaccessible.

\subsection{Zero Pronouns for Metonymic Relation of "Thing for Form"}

\subsubsection{Zero Pronouns for Metonymic Relation of "Thing for Form" from the Same Point of View}

(12) 缝㧅机的长针, Ø 企图将脑子里的思想缝在一起。这是醉后必有的感觉, 虽 Ø难受, Ø倒 也习惯了。Ø翻身下床，Ø眼前出现一片模糊， Ø迷惑于半光圈的分裂。(我应该戒酒，我想。) $\varnothing$ 拉开百叶窝, 原来是个阴䨪的早晨。Ø嘴里苦得很, Ø只是不想吃东西。一种莫名的惆怅, Ø 犹如不齐全的砌图, Ø使我感到莫名的烦恼。天气转冷了, Ø必须取出旧棉袄。(刘以它《酒徒》)

The long needles of sewing machine. $\varnothing$ Trying to sew fragments of thoughts together.The feeling after drunkenness. $\varnothing$ Terrible but $\varnothing$ accustomed. ØTurn over the bed. $\varnothing$ Vague before me. $\varnothing$ Lost in the semi-aperture splitting. ( $\underline{\underline{I}}$ should quit drinking, $\underline{\underline{I}}$ think.) $\varnothing$ Pull the blind. It turns out to be a gloomy morning. Ø Awfully bitter in my mouth. Ø No appetite. A strange melancholy. Like incomplete bricklaying. Send me strange upset. It is turning cold. Ø Must take out the old padded jacket. (Liu Yichang, The Drunkard)

In this segment, a "DECADENT I" ICM is activated. A chain of zero pronouns occur before and after the first pronoun singular "I", between both of which a metonymic relation of "THING FOR FORM" is realized. Hence, conventionalized metonymy $=1$, inferencing step $=1$, the sum total $=2$. The encoding of anaphora tends to be mentally accessible.

\subsubsection{Zero Pronouns for Metonymic Relation of "Thing for Form" from Different Points of View}

(13) (1) $\mathrm{Mr} \mathrm{Bloom}_{\mathrm{i}}$ came to Kildare street. (2) First I must. (3) $\emptyset_{\mathrm{i}}$ Library. (4) Straw hat in sunlight. (5) Tan shoes $j_{j}$. (6) Turnedup trousers $\mathrm{j}_{\mathrm{j}}(7) \mathrm{It}_{\mathrm{j}} \mathrm{is}$. (8) $\mathrm{It}_{\mathrm{j}}$ is. (9) His $\mathrm{Hi}_{\mathrm{i}}$ heart quopped softly. (10) $\emptyset_{\mathrm{i}}$ To the right. (11) $\emptyset_{\mathrm{i}}$ Museum. (12) Goddesses. (13) He swerved to the right. (14) Is it $\mathrm{i}_{\mathrm{j}}$ ? (15) $\emptyset_{\mathrm{i}}$ Almost certain. (16) $\varnothing_{\mathrm{i}}$ Won't look. (17) $\varnothing_{\mathrm{i}}$ Wine in my face. (18) Why did $\mathrm{I}_{\mathrm{i}}$ ? (19) $\varnothing_{\mathrm{i}}$ Too heady. (20) Yes, $\mathrm{it}_{\mathrm{j}}$ is. (21) The walk. (22) $\varnothing_{\mathrm{j}}$ Not see $\varnothing_{\mathrm{i}}$. (23) $\varnothing_{\mathrm{j}}$ Get on. (24) $\varnothing_{\mathrm{i}}$ Making for the museum gate with long windy steps he lifted his eyes. (25) Handsome building. (26) Sir Thomas Deane designed $\emptyset_{\mathrm{x}}$. (27) $\varnothing_{\mathrm{j}}$ Not following me? (28) $\emptyset_{\mathrm{j}}$ Didn't see me perhaps. (29) Light $\mathrm{j}_{\mathrm{j}}$ in his eyes. (30) The flutter of his $\mathrm{s}_{\mathrm{i}}$ breath came forth in short sighs. (30) The flutter of his $s_{i}$ breath came forth in short sighs. (31) $\varnothing_{i}$ Quick. (32) Cold statues: quiet there. (33) $\varnothing_{\mathrm{i}}$ Safe in a minute. (34) No. $\varnothing_{\mathrm{j}}$ Didn't see me. (35) $\varnothing_{\mathrm{j}}$ After two. (36) $\varnothing_{\mathrm{i}}$ Just at the gate. (37) $\mathrm{My}_{\mathrm{i}}$ heart! (38) His $\mathrm{i}_{\mathrm{i}}$ eyes beating looked steadfastly at cream curves of stone. (39) Sir Thomas Deane was the Greek architecture. (40) Look for something $\mathrm{I}_{\mathrm{i}}$. (41) His $\mathrm{H}_{\mathrm{i}}$ hasty hand went quick into a pocket, took out, read unfolded Agendath Netaim. (42) Where did $\mathrm{I}_{\mathrm{i}}$ ? (43) $\varnothing_{\mathrm{i}}$ Busy looking. (44) He $\mathrm{e}_{\mathrm{i}}$ thrust back quick Agendath. (45) Afternoon she said. (46) $I_{i}$ am looking for that. (47) Yes, that. (48) $\emptyset_{\mathrm{i}}$ Try all pockets $_{\mathrm{y} .}$ (49) Handker H. (50) Freeman $_{\mathrm{y} .}$ (51) Where did $\mathrm{I}_{\mathrm{i}}$ ? (52) Ah, yes. Trousers $\mathrm{y}_{\mathrm{y}}$ (53) Purse $_{\mathrm{z} .}$ (54) 
Potato $_{z}$ (55) Where did I? (56) Ø $\varnothing_{\mathrm{i}}$ Hurry. (57) $\varnothing_{\mathrm{i}}$ Walk quietly. (58) $\varnothing_{\mathrm{i}}$ Moment more. (59) $\mathrm{My}_{\mathrm{i}}$ heart. (60) $\mathrm{His}_{\mathrm{i}}$ hand looking for the where did $\mathrm{I}_{\mathrm{i}}$ put found in his hip pocket soap lotion have to call tepid paper stuck. (61) Ah soap there I yes. (62) Ø $\varnothing_{\mathrm{i}}$ Gate. (63) $\emptyset_{\mathrm{i}}$ Safe! (Joyce, Ulysses)

The following inferencing is supposed to be made for the resolution of anaphors in this segment:

(1) activation of a "TWO BLOOMS" ICM;

(2) the same "Bloom" within segments;

(3) different representations of "Bloom" across segments.

This segment approaches Bloom's chain of fluttered activities in the real world from both perspectives, i.e., an objective point of view and a subjective point of view. The subjective point of view subsegments are neatly embedded in the objective point of view segment. Sentences (1), (9), (13), (24), (38), (41), (44) and (60) provide a chain of platforms or piers the stream of consciousness by "Bloom" temporarily dwells upon. While sentences (42), (51) and (55) are markers for the subjective point of view, signaling the subconscious stream flowing in Bloom's mind. The explicit antecedents in sentences (1), (9), (13), (24), (38), (41), (44) and (60), together with zero pronouns in sentences (42), (51) and (55) play the dual function of marking perspective alteration and maintaining textual coherence from different points of view. They activate "TWO BLOOMS" ICM, an explicit "Bloom" of the objective world, and a non-explicit "Bloom" of the psychological world. They shuffle back and forth in a natural manner. Within the subjective point of view segment, a metonymic relation of "FORM FOR FORM" is established. Hence, conventionalized metonymy $=1$, inferencing step $=1$, the sum total $=2$. The encoding of anaphora within segments tends to be mentally accessible. Within the objective point of view segment, a metonymic relation of "THING FOR THING" is established. Conventionalized metonymy $=1$, inferencing step $=1$, the sum total $=2$. The encoding of anaphora within segments tends to be mentally accessible. Whereas across segments, nonce metonymy $=2$, inferencing step $=2$, the sum total $=4$. The encoding of anaphora across segments tends to be mentally inaccessible.

\subsection{Zero Pronouns for Metonymic Relation of "Concept for Form"}

\subsubsection{Zero Pronouns for Metonymic Relation of "Concept for Form" for Particular Reference}

(14) A soft qualm, regret, flowed down his backbone, increasing. $\varnothing_{\mathrm{i}}$ Will happen, yes. $\varnothing_{\mathrm{j}}$ Prevent $\varnothing_{\mathrm{i}} . \varnothing_{\mathrm{x}}$ Useless: can't move. Girl's sweet light lips. $\varnothing_{i}$ Will happen too. He felt the flowing qualm spread over him. $\varnothing_{\mathrm{y}}$ Useless to move now. Lips kissed, kissing, kissed. Full gluey woman's lips. (Joyce, Ulysses)

In this segment, an ICM of father's qualm and helplessness about his daughter's love affairs as a grown-up is activated. The metonymic relation of zero pronouns is "Concept for Form", i.e., qualm for zero pronouns, in which conventionalized metonymy $=1$, inferencing step $=1$, the sum total $=2$. The encoding of anaphora tends to be mentally accessible.

3.6.2 Zero Pronouns for Metonymic Relation of “Concept for Form” for General Reference

(15) 这里很暖。……这里 Ø能看见东风饭店的 25 层楼的灯火。这里 Ø能听见火车站的悠扬的钟 声。这里 Ø能看见海关大楼的电钟。Ø 把视线转到下面, 是蓝绿的灯珠, 橙黄的灯眼, 银白的灯 花。无轨电车的天弓打着闪亮的电火花。(王蒙《风筝飘带》)

It is warm here... at which the lights on the 25 th floor of Dongfeng Hotel can be seen $\varnothing$, the melodious clock chimes can be heard $\varnothing$, and the electric clock of the Customs Building can come into $\varnothing$ view. Aquamarine blue lamps, orange light bulbs, argent snuff and the trolleybus are in a bird's eye $\varnothing$ view. (Wang Meng, Kite Streamers)

In this segment, a "BUSTLING DOWNTOWN AREA" ICM is evoked in readers' mind. Zero pronouns are employed for general reference of anyone paying a visit here. Hence, a metonymic relation of "Concept for Form" for general reference is established, in which conventionalized metonymy $=1$; inferencing step $=1$; the sum total $=2$. The encoding of anaphora tends to be mentally accessible.

\section{Discussion and Conclusion}

Seven types of metonymic relations between antecedent and anaphor in the in-depth analysis of SOC segments are discerned, i.e., CONCEPT FOR CONCEPT, CONCEPT FOR THING, THING FOR THING, THING FOR CONCEPT, which is subsumed into the level of cognition and coherence; while CONCEPT FOR FORM, FORM FOR FORM and THING FOR FORM into the level of formal signification and cohesion. Therefore, we can corroborate the hypothesis that anaphora resolution in SOC discourse is to a great extent constrained by two factors: (1) conceptual distance between anchor and anaphor; (2) optimal relevance. 
The metonymic model and principles of anaphora resolution based on SOC discourse may be applicable to other types of discourse as well.

(16) a. Slice the onion finely, brown $i t_{i}$ in the butter and then place $i t_{j}$ in a small dish.

b. Kill an active, plump chicken. Prepare $i_{i}$ for the oven, cut $i_{j}$ into four pieces and roast $i_{k}$ with thyme for 1 hour. (Brown \& Yule, 1983)

In example (a), $i t_{i}$ is disjoint with $i t_{j}$ at the cognitive level, with $i t_{i}$ as onion just bought from the market and with $\mathrm{it}_{\mathrm{j}}$ as onion just chopped up. They are different states of an onion in the "RECIPE" ICM. A metonymic relation of "Thing for Thing" is realized. Hence, part-for-whole metonymy $=1$, inferencing step $=1$, the sum total $=2$. The encoding of anaphora tends to be mentally accessible. The same also applies to example (b)

In short, both cognitive and pragmatic constraints on anaphora resolution interact, and the division of labor between them can be measured according to conceptual distance of antecedent and anaphor and degrees of optimal relevance. The metonymic approach to SOC discourse anaphora resolution is actually a cognio-pragmatic inferencing process in which the hearer/reader achieves optimal relevance on the basis of the conceptual distance between antecedent and anaphor in ICM.

\section{References}

Al-Sharafi, A. G. M. (2004). Textual Metonymy: A Semiotic Approach. London: Palgrave Macmillan. http://dx.doi.org/10.1057/9781403938909

Ariel, M. (1990). Assessing Noun-Phrase Antecedents. London: Routledge.

Ariel, M. (1994). Interpreting anaphoric expressions: A cognitive versus a pragmatic approach. Journal of Linguistics, 30, 3-42. http://dx.doi.org/10.1017/S0022226700016170

Barcelona, A. (2002). Clarifying and applying the notions of metaphor and metonymy within cognitive linguistics: An update. In R. Dirven, \& R. Rörings (Eds.), Metaphor and Metonymy in Comparison and Contrast (pp. 207-277). Berlin: Mouton de Gruyter. http://dx.doi.org/10.1515/9783110219197.207

Brown, G., \& Yule, G. (1983). Discourse Analysis. Cambridge: Cambridge University Press. http://dx.doi.org/10.1017/CBO9780511805226

Chomsky, N. (1982). Some Concepts and Consequences of the Theory of Government and Binding. Cambridge, Massachusetts: MIT Press.

Croft, W., \& Cruse, D. A. (2004). Cognitive Linguistics. Cambridge: Cambridge University Press. http://dx.doi.org/10.1017/CBO9780511803864.002

Fox, B. A. (1987). Discourse Structure and Anaphora: Written and Conversational English. Cambridge: Cambridge University Press. http://dx.doi.org/10.1017/CBO9780511627767

Gibbs, R. W. (2007). Experimental tests of figurative meaning construction. In G. Radden, K.-M. Köpcke, T. Berg, \& P. Siegmund (Eds.), Aspects of Meaning Construction. Amsterdam: John Benjamins.

Givón, T. (1983). Topic continuity in discourse: An introduction. In T. Givón (Ed.), Topic Continuity in Discourse: A Quantitative Cross-Language Study (pp. 1-42). Amsterdam: John, Benjamins. http://dx.doi.org/10.1075/tsl.3

Givón, T. (1990). Syntax: A Functional-Typological Introduction (Vol. 2). Amsterdam: John Benjamins.

Grice, H. P. (1989). Studies in the Way of Words. Cambridge: Harvard University Press.

Grosz, B. J., \& Sidner, C. L. (1986). Attentions, intentions and the structure of discourse. Computational Linguistics, 12, 175-204.

Grosz, B. J., Joshi, A. K., \& Weinstein, S. (1995). Centering: A framework for modeling the local coherence of discourse. Computational Linguistics, 21(2), 203-225.

Halliday, M. A. K. (1981). Explorations in the Functions of Language. London: Edward Arnold.

Halliday, M. A. K., \& Hasan, R. (1985). Language, Context and Text: Aspects of Language in a Social-semiotic Perspective. Oxford: Oxford University Press.

Halliday, M. A. K., \& Matthiessen, C. (1999). Construing Experience through Language: A Language-based Approach to Cognition. London: Cassell.

Huang, Y. (1991). A neo-Gricean pragmatic theory of anaphora. Journal of Linguistics, 27, 301-335. http://dx.doi.org/10.1017/S0022226700012706 
Huang, Y. (1994). The Syntax and Pragmatics of Anaphora: A Study with Special Reference to Chinese. Cambridge: Cambridge University Press. http://dx.doi.org/10.1017/CBO9780511554292

Huang, Y. (2000). Anaphora: A Cross-linguistic Study. Oxford: Oxford University Press.

Joyce, J. (1986). Ulysses. London: Penguin Books. http://dx.doi.org/10.5007/1980-4237.2010n8p411

Lakoff, G. (1987). Women, Fire, and Dangerous Things: What Categories Reveal about the Mind. Chicago: University of Chicago Press. http://dx.doi.org/10.7208/chicago/9780226471013.001.0001

Levinson, S. C. (1989). A review of relevance. Journal of Linguistics, 25, 455-472. http://dx.doi.org/10.1017/S0022226700014183

Liu, Y.-C. (1963). Jiu Tu (The Drunkard). Xianggang: Xianggang Binhai Tushu Gongsi (Hong kong Coastal Press).

Miltsakaki, E. (1999). Locating topics in text processing. Computational Linguistics in the Netherlands: Selected Papers from the Tenth CLIN Meeting (pp. 127-138). Utrecht.

Miltsakaki, E. (2002). Toward an aposynthesis of topic continuity and intrasentential anaphora. Computational Linguistics, 28(3), 319-355. http://dx.doi.org/10.1162/089120102760276009

Miltsakaki, E. (2007). A rethink of the relationship between salience and anaphora resolution. Proceedings of the 6th Discourse Anaphora and Anaphora Resolution Colloquium (pp. 91-96). Lagos, Portugal.

Panther, K.-U., \& Radden, G. (Eds.). (1999). Metonymy in Language and Thought. Amsterdam: John Benjamins. http://dx.doi.org/10.1075/hcp.4

Panther, K.-U., \& Thornburg, L. L. (Eds.). (2003). Metonymy and Pragmatic Inferencing. Amsterdam: John Benjamins. http://dx.doi.org/10.1075/pbns.113

Papafragou, A. (1996). On metonymy. Lingua, 99, 169-195. http://dx.doi.org/10.1016/0024-3841(96)00016-2

Radden, G., \& Kövecses, Z. (1999). Towards a theory of metonymy. In K.-U. Panther, \& G. Radden (Eds.), Metonymy in Language and Thought (pp. 17-59). Amsterdam: John Benjamins. http://dx.doi.org/10.1075/hcp.4.03rad

Ruiz de, M., Francisco, J., \& Pérez, H. L. (2003). Cognitive operations and pragmatic implication. In K.-U. Panther, \& L. L. Thornburg (Eds.), Metonymy and Pragmatic Inferencing (pp. 23-49). Amsterdam: John Benjamins.

Sperber, D., \& Wilson, D. (1986). Relevance: Communication and Cognition. Oxford: Basil Blackwell. http://dx.doi.org/10.1017/S0140525X00055345

van Hoek, K. (1992). Paths through Conceptual Structure: Constraints on Pronominal Anaphora (Unpublished doctoral dissertation). University of California, San Diego, America.

van Hoek, K. (1995). Conceptual reference points: A cognitive grammar account of pronominal anaphora constraints. Language, 71, 310-340. http://dx.doi.org/10.2307/416165

Wang, M. (1993). Wang Meng wenji (yi zhi shi juan) (The collected works of Wang Meng vol.1-10). Beijing: Huyi Chuban She (Huayi Press, Beijing).

\section{Copyrights}

Copyright for this article is retained by the author(s), with first publication rights granted to the journal.

This is an open-access article distributed under the terms and conditions of the Creative Commons Attribution license (http://creativecommons.org/licenses/by/3.0/). 